\title{
Criteria for the Establishment of the Public Property Institution from the Perspective of General Administrative Law
}

The study of the public property institution formation process in the system of general administrative law should be started with some clarification of the institutional features of the legal system. A comprehensive analysis of law sources containing legal norms regarding public property clearly demonstrates that the public property institution is a fairly wide legal category; it sets up the general essential features of public property as well as possibilities of its use and the procedure for public administration in this field. The said legal institution acts as a legal phenomenon structuring a set of legal norms regarding the establishment of legal frameworks for various types of public property.

It should be stated straight away that, as S.V. Nesynova rightly notes, there is no unity of approaches to the essence of that legal institution, in particular to public property as a legal category ${ }^{2}$. Nevertheless, it should be clarified that the structuring of legal norms, not least in the field of public property, is extremely topical, taking into account the formation historical paradigm and essential features of public property.

In the regulatory context, this will allow for optimisation of the mechanism of public property administration as well as the interaction between public and private law entities in terms of its use. In this regard, A.S. Avtonomov observes the views according to which the legal institution is ontological phenomena determining the patterns of formation and development of the corresponding legal categories; a combination of legal norms establishing the legal basis for the implementation of homogeneous social relations within a particular country as well as similar legal institutions of other countries ${ }^{3}$.

\footnotetext{
${ }^{1}$ Nataliia Yuriivna Zadyraka, Candidate of Judicial Sciences, Associated Professor, Associated Professor of Administrative Law Department, Faculty of Law Kyiv National Taras Shevchenko University.

${ }^{2}$ S.V. Nesynova, Law, Legal Category, Legal Institution: Problems of Determination, „Scientific Bulletin of Kherson State University” 2014, Vol. 2, No. 1, p. 103-108, 106.

${ }^{3}$ A.S. Avtonomov, Legal Ontology of Politics. To the Construction of a Category System, Moscow: Company Infograph LLC 1999, p. 20.
} 
Thus, it can be stated that the formation of the public property institution in the system of general administrative law has provided for the institutionalisation of a complex legal core mentioned above for the standardisation of legal norms in a complex formation. From the perspective of the provisions stated here, S.S. Alekseev perceives the legal institution as a specific primary structural element ${ }^{4}$ and consequently O.I. Yushchik interprets this legal category as a "normative-legal way of recognising the necessity of a public institution" ${ }^{2}$. According to our opinion, it is by the nature and orientation of the subject of legal norm regulation in the field of public property that one can establish the systemic-institutional pertinence of this legal entity.

At the same time, it is necessary to establish the individualisation of such legal norms, including in order to optimise the legal framework in the field of public property use and administration, which should be formed by clearly defining the place of these legal norms. Such conditions must be achieved due to the stability of subjective and objective properties of the relations that are a part of the administrative and legal support in the field of public property use as well as a public and administrative component taking into account the needs and interests of civil society considering ontological, axiological, epistemological, positivistic, pragmatic and realistic criteria.

In particular, in functional terms, the ontological criterion allows for establishing the procedure for the formation of the public property institution as a constituent element of administrative law. Thus, in the ontological dimension, it is first necessary to focus on the legal nature of relations in the field of public property use as an objective reality in external relations and from the point of view of constructivism in internal relations. In foreign doctrine, there is the scientific opinion that in this case it is about the grounds of constructivism in the formulation of ontological assumptions and the interpretation of objective characteristics ${ }^{6}$. Following that approach, the place of the public property institution as an element of the general administrative law system is determined by the social orientation of using such property, taking into account its institutional features, within the limits of a changing legal reality.

Alternatively, in epistemological terms, the formation of the public property institution in the system of general administrative law, it is necessary to focus on assumptions about the acceptance of the application of relevant legal categories as well as on a qualitative approach when inter-

\footnotetext{
${ }^{4}$ S.S. Alekseev, Structure of Soviet Law, Moscow: Legal Lit., 1975, p. 63.

${ }^{5}$ O.I. Yushchik, Fields and Institutes of the Legal System (Myths and Reality), Kijev: Oriiani 2002, p. 54-59.

${ }^{6}$ P.W. Ihuah, D. Eaton, The Pragmatic Research Approach: A Framework for Sustainable Management of Public Housing Estates in Nigeria, "Journal of US-China Public Administration" 2013, Vol. 10, No. 10, p. 936.
} 
preting the latter. At the same time, subjective characteristics of the social dimension of public property dominate, taking into account a motivational component of participants in administrative legal relations in the field of legal protection and use of public property. These actors play a crucial role in determining the place of the said property institution in the administrative law system. Accordingly, the epistemological criterion is closely intertwined with the axiological factor of public property institutionalisation. In fact, as it is pointed out by R. Ihuah and D. Eaton, the axiological criterion is based on the categories of neutrality by not using evaluative judgments and on the basis of judgments about values, taking into account subjective properties ${ }^{7}$.

Therefore, the qualitative reflection of criteria for the formation of the public property institution in the system of general administrative law described above is not sufficient for the full identification of the relevant systemic and structural relations. Hence, the use of quantitative and mixed criteria of institutionalisation in the field of public property can be considered as accepted practice. In essence, one must agree with foreign scholars that it is reasonable to add quantitative and qualitative, positivistic and pragmatic criteria to the 'pure' qualitative ontological, axiological and epistemological approaches as well as the instruments of the realist approach ${ }^{8}$. For example, from the pragmatic point of view, when formulating the criteria for public property institutionalisation, it is necessary to take into account the social realities of life in the field of public property use on the basis of which the interpretation of such property administration effectiveness is made. The realism of such criteria is expressed in their objectivity and independence in interpreting legal facts on the basis of world-wide views, cultural characteristics and experience in the field of legal regulation.

Further exploring the notion of quantitative and mixed criteria for the establishment of the public property institution, it is reasonable to characterise the quantitative legal instruments of the positivistic orientation of understanding the criteria for the formation of the public property institution. In this respect, the positivistic aspect of understanding the systematisation of administrative law will allow for implementing the epistemology of the formation of the public property institution in the most effective way, taking into account the objectivity of the process and independence from subjective factors. From the standpoint of positivism as a mono-method, it is about taking into account the categories of objectivity, factual reliability and cause-and-effect relationships.

In general, one can formulate the interim conclusion that constructivism, naturalism, interpretation and introduction of quantitative and qualitative criteria for the formation of the public property institution in the

\footnotetext{
Ibidem, p. 937-938.

${ }^{8}$ Ibidem, p. 938.
} 
system of general administrative law allow for taking into account the social dimension of relations in connection with the administration of such property, the economic dimension of such activity on the basis of a holistic legal philosophical approach. This creates conditions for ensuring the depth and breadth of the mechanism of administrative and legal support for the implementation of public property legal frameworks.

Therefore, it can be stated that in terms of the presented ontological, epistemological, axiological, positivistic, pragmatic and realistic criteria for the formation of the public property institution in the system of general administrative law, it is necessary, above all, to be guided by the subject and regulative characteristics of these categories. Essentially, in the objective and causal dimensions, one can agree with F.S. Fatkullin that according to the subject of legal regulation it is possible to establish a "measure of qualitative specificity" of the formation of legal institution".

At the same time, the common generic features of relations in the field of public administration and the use of public property indicate a generic relationship of this institution with other constituent elements of the system of general administrative law. The point is the establishment of powers of public administration and users of public property as well as the autonomy of the legal status of participants in administrative legal relations regarding the use of public property and administrative legal methods of protection in this field.

It is no less important to take into account the restrictive orientation of these criteria for the institutionalisation of legal norms regarding public property. It is also necessary to clarify that the external and internal laws of the subject-regulating field in the use of public property unambiguously coincide with the basic postulates of administrative law. Therefore, according to E.N. Trubetskoy, it is worth taking into account both the provision and the restriction of external freedom by legal norms ${ }^{10}$. In this way, the institution of public property is aimed at the formation of a procedure for regulating administrative legal relations in the field of public property use in a heuristic dimension. Such institution should be considered as a subsystem establishing variations of the genesis and functioning of adjacent institutions of general administrative law.

It follows that in an abstract and specific context, the attribution of these legal norms to the institution of the general administrative law system is based on understanding of trends in the knowledge of the objective characteristics of public property. These features serve as the basis for taking into account new developments in the doctrine and practices of public law, in particular, in an administrative and legal context.

\footnotetext{
${ }^{9}$ F.N. Fatkullin, Problems of the Theory of State and Law. Course of Lectures, Publication of Kazan University 1987, p. 186-189.

${ }^{10}$ E.N. Trubetskoy, Encyclopedia of Law, St. Petersburg: Publishing house Lan 1998, p. 14, 16, 21.
} 
At the same time, one should also proceed from the assumption that the criteria for attributing the public property institution to the system of general administrative law has a dynamic context, which is reflected through similar functions of the institutions of general administrative law. At the doctrinal level, this approach is supported by L.I. Spiridonov ${ }^{11}$ et al. In addition, the dynamic criterion is closely related to the axiological one taking into account the main system-forming role of functions and the anthropocentric orientation of administrative law in relation to its institutions. It also allows for minimising internal contradictions between the constituent elements of the system of general administrative law when differentiating its institutions, while simultaneously attributing them to a single system-forming core of the branch of law mentioned. The postulates described here appear during the formalisation of the institutions of administrative law by harmonising the interests of the subjects of public and private law. In this respect, in relation to the dynamic criterion of attributing the public property institution to the system of general administrative law, it is necessary to consider the trends of filling the relevant administrative legal relations with meaning. These fundamental categories are crystallised in the legal reality regarding the cooperation of public administration and civil society representatives in public property administration on an anthropocentric basis.

In fact, both the statics and dynamics of the criteria for the formation of the public property institution in the system of general administrative law stipulate the essential regulatory aspects of the entire complex of legal norms regarding the establishment and development of the mechanism of administrative and legal support in the field of public property use. It means the similarity of the regulatory features of the content of the public property institution with the traditional institutions of general administrative law, primarily through the content of disposition of the relevant legal norms. In this respect, O.I. Yushchik explains that the subject of legal norms is a sufficient and consistent criterion for grouping them into a legal institution and establishing its system and structural pertinence ${ }^{12}$.

It is also important to take into account the hierarchical pyramidal system-forming role of criteria for the formation of the public property institution in the system of general administrative law. Such criteria allow, in logical and evaluative terms, for ensuring the unity of administrative law norms within its institutions based on historical realities and the freedom of the subjects of law-making and law enforcement. Thus, one can state that the 'design' dimension of the criteria for the formation of the public property institution results directly from the essential regulatory orientation of

${ }^{11}$ L.I. Spiridonov, State and Law Theory, Moscow [b.v.], 1995, p. 175; V.D. Sorokin, Legal Regulation: Subject, Method, Process, „Law Science” 2000, Vol. 4, p. 34-35.

${ }^{12}$ O.I. Yushchik, Fields and Institutes..., p. 26-29. 
administrative and legal relations in the field of public administration and the use of public property. In this respect, the definition of the place and essential modelling of the public property institution in the system of general administrative law allow for ensuring a renewal of a conglomerate of legal norms within its boundaries, taking into account the latest trends in theory and practice in the field of public property. The general orientation of these criteria should be characterised by the optimality, completeness, accuracy and adequacy of the reflection of the regulatory features of the legal norms establishing legal frameworks of various types of public property.

\section{Bibliography}

Alekseev S.S., Structure of Soviet Law, Moscow: Legal Lit. 1975.

Avtonomov A.S., Legal ontology of politics. To the construction of a category system, Moscow: Company Infograph LLC 1999.

Fatkullin F.N., Problems of the Theory of State and Law. Course of lectures, Publication of Kazan University 1987.

Ihuah P.W., Eaton D., The Pragmatic Research Approach: A Framework for Sustainable Management of Public Housing Estates in Nigeria, „Journal of US-China Public Administration" 2013, Vol. 10, No. 10.

Nesynova S.V., Law, Legal Category, Legal Institution: Problems of Determination, „Scientific Bulletin of Kherson State University" 2014, Vol. 2, No. 1.

Sorokin V.D., Legal Regulation: Subject, Method, Process, „Law Science” 2000, Vol. 4. Spiridonov L.I., State and Law Theory, Moscow: [b.v.], 1995.

Trubetskoy E.N., Encyclopaedia of Law, St. Petersburg: Publishing house Lan 1998. Yushchik O.I., Fields and Institutes of the Legal System (Myths and Reality), Kijev: Oriiani 2002.

Abstract

This article concerns the ontological, epistemological, axiological, positivistic, pragmatic and realistic criteria of the formation of the institution of public property in the system of general administrative law. The general orientation of these criteria should be characterised by the optimality, completeness, accuracy and adequacy of the reflection of the regulatory features of the legal norms establishing legal framework of various types of public property.

Keywords: formation of the institution of public property, general administrative law

Kryteria kształtowania instytucji własności publicznej w ogólnym prawie administracyjnym

Streszczenie

Artykuł dotyczy ontologicznych, epistemologicznych, aksjologicznych, pozytywistycznych, pragmatycznych oraz realistycznych kryteriów kształtowania instytucji wła- 
sności publicznej w systemie ogólnego prawa administracyjnego. Ogólna orientacja wymienionych kryteriów powinna charakteryzować się optymalnością, pełnością, dokładnością oraz adekwatnością odzwierciedlenia cech regulacyjnych norm prawnych ustanawiających ramy prawne różnych typów własności publicznej.

Słowa kluczowe: kształtowanie instytucji własności publicznej, ogólne prawo administracyjne 